\title{
RECORDS OF PRAYING MANTIDS (INSECTA: MANTODEA) FROM TWO AREAS OF CENTRAL KALIMANTAN, AND NOTES ON BORNEAN ODONTOMANTIS AND HIERODULA
}

\author{
Philip Edward Bragg \\ 31 Parkhouse Road, Lower Pilsley, Chesterfield, Derbyshire, S45 8DG, U.K. \\ email: pbragg@aol.com
}

Received: 26 April 2021; Accepted: 12 June 2021

\begin{abstract}
Results are presented for a collection of praying mantids from two different habitats in Kalimantan Tengah: an area of peat-swamp forest and an area of hill forest. Forty-one specimens are recorded, representing 20 species; this is the first such collection to be recorded from Kalimantan after more than 70 years. Photographs are included for a number of species, concentrating on species which have not previously been illustrated. Some issues with the Bornean Odontomantis are highlighted and a key to Bornean species is provided. The status of $O$. micantula Beier, 1937 is clarified, the syntypes are located, and the species is illustrated; the synonymy of $O$. planiceps and $O$. javana is questioned. Some historical issues relating to Bornean members of Hierodula are reviewed; the synonymy of $H$. athene Rehn, 1909 and H. hybrida Burmeister, 1838 and H. venosa (Olivier, 1792) is considered doubtful. Issues with identification of $H$. venosa and $H$. vitrea (Stoll, 1813) leave their presence in Borneo questionable.
\end{abstract}

Keywords: Borneo, Central Kalimantan, Hierodula, Mantodea, Odontomantis

\begin{abstract}
ABSTRAK
Hasil yang disajikan di sini merupakan koleksi belalang sembah dari dua habitat berbeda di Kalimantan Tengah: kawasan hutan rawa gambut dan kawasan hutan perbukitan. Empat puluh satu spesimen dicatat, mewakili 20 spesies; ini adalah koleksi pertama yang dicatat dari Kalimantan setelah lebih dari 70 tahun. Foto-foto disertakan untuk sejumlah spesies, berkonsentrasi pada spesies yang belum pernah diilustrasikan sebelumnya. Beberapa masalah dengan Odontomantis Kalimantan disorot dan kunci spesies Borneo disediakan. Status O. micantula Beier, 1937 diklarifikasi, sintipe disebutkan, dan spesies diilustrasikan; sinonim $O$. planiceps dan $O$. javana dipertanyakan. Beberapa masalah historis yang berkaitan dengan anggota Hierodula di Borneo ditinjau; sinonim $H$. athene Rehn, 1909 dan H. hybrida Burmeister, 1838 dan H. venosa (Olivier, 1792) dianggap meragukan. Masalah dengan identifikasi $H$. venosa dan $H$. vitrea (Stoll, 1813) membuat keberadaan mereka di Borneo dipertanyakan.
\end{abstract}

Kata kunci: Borneo, Kalimantan Tengah, Hierodula, Mantodea, Odontomantis

\section{INTRODUCTION}

Praying mantids are one of the most readily recognized type of insect, and are likely to be identified by the general public even in countries where mantids do not occur. Although mantids do use their fore legs when climbing, they are distinguished by their habit of standing on only four legs with their heavily spined fore legs raised above the ground and folded ready 
to strike at their prey; this behavior is almost unknown in other insect orders. The general public often associate mantids with sexual cannibalism: the females have a reputation for eating the male during copulation; although cannibalism can occur when they are disturbed, the frequency of this under natural conditions is unclear. Mantids will feed both in daylight and at night; they feed mainly on insects, although some large species have been recorded eating birds, mammals and lizards. Females lay their eggs in large batches which are surrounded by a foam which hardens into a protective casing known as an ootheca. Females are heavier than males because of the eggs and therefore generally do not fly as readily as males; this is most evident in large species where a heavily laden female may be incapable of true flight. In some species females are brachypterous or apterous while the males may be macropterous. Mantids are predominantly tropical insects although a considerable number occur in subtropical regions, and a few occur in cooler temperate regions of the world. Of about 2500 species worldwide, over 120 species are known to occur on Borneo, but the records are so sparse that many species have only been recorded once.

In August 1993 I joined a botanical team from Nottingham University, who were working on the "For Peat's Sake" research project in collaboration with Palangkaraya University. At the time I was studying for a $\mathrm{PhD}$ in entomology, specialising in the stick insects (Phasmida) of Borneo. The main aim in joining the botanical group was to evaluate the phasmid diversity in the area; however, my interest in mantids led me to collect any that were encountered by chance. Specimens were collected in the botanical research area near Kelembenkari (Fig. 1) over five nights. I then traveled upriver to Tewah and, following a chance meeting with the foreman, was invited to stay at Ratu Miri Logging Camp (Fig. 1) where I collected for six nights before rejoining the group at Palangkaraya and collected for a further four nights. One phasmid was also collected from a garden in Palangkaraya shortly before my return to the UK. Some Blattodea and Orthoptera were also collected at Ratu Miri. In 1994 some mantids were collected at Kelembenkari by Paul Jenkins, a long-term member of the Nottingham botanical group, and sent to me for identification. Records for many of the phasmids have already been published (Bragg, 2001, 2005, 2008a), as has a record for one species of cockroach (Bragg, 1997a). Results for mantid specimens in the genera Humbertiella, and Theopompa have already been recorded elsewhere (Bragg, 2010). A total of 41 specimens of mantids were recorded: 15 from Ratu Miri and 26 from Kelembenkari. While attempting to identify some species of Hierodula Burmeister, 1838 a review of the oldest supposed Bornean species of the genus was found to be necessary. 


\section{MATERIALS AND METHODS}

All specimens recorded here are in my personal collection. Specimens in my collection have individual accession numbers prefixed by PEB-M; this numbering system was not introduced until some years after the specimens were collected so the numbering is not sequential for the material from Kalimantan. Species collected in 1994 by Paul Jenkins were also given code numbers by him at the time of collection. Partly due to the variety of languages in use, spellings of place names in Borneo vary on different maps; here I use the spellings which were originally given to me, and used on my data labels: I also give known alternatives in brackets.

The base for the botanical research group was a logging camp about $1 \mathrm{~km}$ downstream from Kelembenkari (Kelem Benkari = Kereng Benkirai), a village on the banks of the Sungai Sebangau, about $10 \mathrm{~km}$ south of Palangkaraya (Palangka Raya). The collecting area was mainly logged peat swamp forest, or primary low pole forest. I collected material at two locations: close to the base camp (eight nights), and at "Bukit Jak" (one night). Bukit Jak is a small granite outcrop rising about $50 \mathrm{~m}$ above the surrounding swamp forest located about $10 \mathrm{~km}$ south of the base camp and accessed by a narrow-gauge railway line; it was named Bukit Jak after Dr. Jack Rieley, the organiser of the botanical research group from Nottingham University. Material later collected by Paul Jenkins was from near the base camp. Latitude and longitude for the two sites near Palangkaraya were obtained by use of a GPS unit by a member of Palangkaraya University; Base camp: 113 54'30'E $02^{\circ} 19^{\prime} 02^{\prime \prime}$; ; Bukit Jak: $113^{\circ} 52$ '34”'E $02^{\circ} 23$ '43”S.

The location of Ratu Miri logging camp has only been estimated, neither the Sungai Ratu Miri nor the logging camp have been located on any map. While there, I was told Sungai Ratu Miri is a tributary of Sungai Mirih. To reach the logging camp from Tewah, I travelled upstream for a short distance, landing on the north bank of the river Kahajan (=Kahayan), then overland on a logging truck for several hours in a northerly direction. A recent search on the internet showed the company, PT Ratu Miri, was given a logging rights to 42,000 hectares in the Sungai Mirih area in 1988 (Supreme Court, 2008) but I have been unable to find any precise location. For data labels, and previously published results, I have estimated the camp to be near $113^{\circ} 35^{\prime} \mathrm{E} 00^{\circ} 40^{\prime} \mathrm{S}$. The area was primary hill forest but some of the area near the camp had been recently logged. 


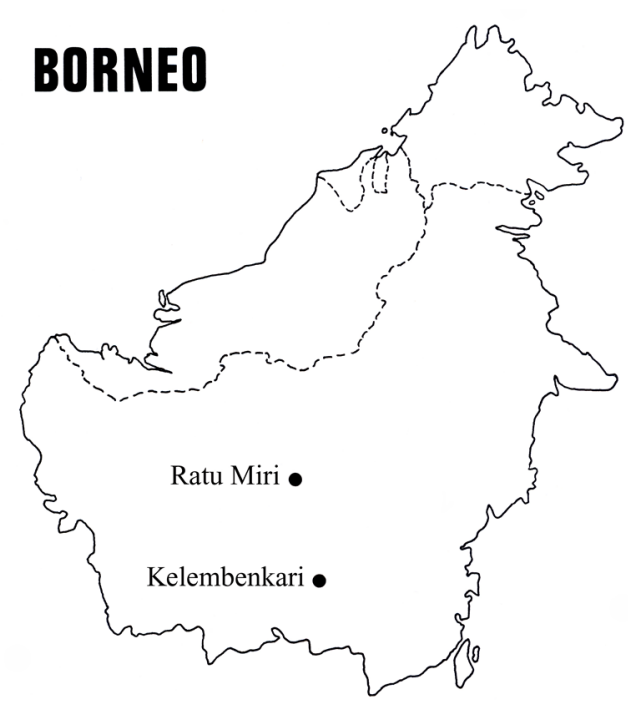

Figure 1. Map showing collecting sites.

In both areas specimens of mantids were collected in a casual manner, i.e. not by actively searching for mantids, but by collecting them when they were encountered while searching for phasmids. Phasmids are predominantly nocturnal but rarely attracted to light, however, the illuminated areas of the logging camp were checked at least once each night. Mantids are also very active at night and often attracted to lights; most of the mantids were found at lights. The record for one specimen is based on a photograph only, the specimen was not collected.

Identification of mantids in the genus Hierodula Burmeister, 1838 presents significant problems due to inadequate original descriptions. Preparations of the genitalia have allowed three species to be associated with recently published material collected elsewhere in Borneo (Schwarz \& Roy, 2019); however, I have retained my numbering for species for which I consider the identification doubtful.

Genitalia were removed, cleared in $10 \%$ potassium hydroxide $(\mathrm{KOH})$, and mounted in Euparal (for method see Bragg, 2008b: 193). Photographs of the genitalia slides were taken with a tripod-mounted Canon digital SLR fitted with a $60 \mathrm{~mm}$ "macro" lens and a $25 \mathrm{~mm}$ extension tube. Genitalia photographs were cleaned up using Adobe Photoshop Elements software to reposition elements of the genitalia which moved out of position during slide preparation; air bubbles surrounding the genitalia were also removed, but were left if under or over the genitalia. Photographs of the genitalia show the conventional ventral view. 
Photographs of whole insect specimens were taken with a Canon digital SLR and 60 mm lens. The photographic record of Haania sp. was made with a Praktica MTL3 fitted with a $50 \mathrm{~mm}$ lens, using 100 ASA slide film; this was transferred to digital format using a flatbed scanner. Scale lines on photographs are $1 \mathrm{~cm}$ on whole insects, and $1 \mathrm{~mm}$ on genitalia.

Stoll (1787) illustrated two species which are currently treated as Bornean Hierodula. The only potentially useful measurements that can be taken from Stoll's drawings are the lengths of the pronotum (p) and elytra (e). To evaluate the reliability of measurements from Stoll's drawings a readily identifiable species, Hymenopus coronatus (Olivier, 1792), was chosen and measurements taken from my specimens (two from Sabah PEB-217, PEB-218; and one from peninsular Malaysia, PEB-116), and from Stoll's drawings. In addition to the material from Kalimantan, measurements of Hierodula species H3 and H5 were taken from all the specimens in my personal collection. Measurements of Hierodula specimens were made using digital calipers. Measurements were made to the nearest $1 \mathrm{~mm}$ for elytra length and the nearest $0.5 \mathrm{~mm}$ for pronotum length, and the e/p values calculated (Table 1).

Outline drawings of the pronota of Odontomantis micantula Beier, 1956 were made with a binocular microscope fitted with a camera lucida. An outline drawing of the pronotum of O. rhyssa Werner, 1930 was made from a photocopy of Werner's illustration, then Werner's measurements and photoshop software was used to adjust it to the same scale. A similar process was carried out with printouts from scanned illustrations of $O$. planiceps (De Haan, 1842) and $O$. javana (Saussure, 1870). The illustration by De Haan (1842: plate 17 fig. 10) was produced life-size, and the digital copy available to me is fairly low quality, so this outline in particular should be treated with some caution. Measurements of Odontomantis specimens were made using an eyepiece graticule and recorded to the nearest $0.1 \mathrm{~mm}$.

\section{RESULTS}

The specimens were collected almost exclusively at night, with the majority having been attracted to lights around buildings. Male mantids generally fly more readily than females, consequently 34 of the 41 specimens are male. Of the seven females only one (Haania sp.) is known to have been found in daylight, the other females are all small species which fly well. Within each of the three collection areas (Ratu Miri, Kelembenkari Base camp, Bukit Jak), the specimens are listed alphabetically by genus, then species. 
Ratu Miri (113 $\left.35^{\prime} \mathrm{E} 00^{\circ} 40^{\prime} \mathrm{S}\right)$.

Amorphoscelis rufula Roy, 1967

§ิ PEB-M62, to light, P.E. Bragg, viii.1993.

Camelomantis giraffa (Giglio-Tos, 1912) (Fig. 2)

ô PEB-M43 to light, P.E. Bragg, viii.1993.

Creobroter episcopalis Stål, 1877 (Fig. 3)

ઈ̋ PEB-M51, đ̊ PEB-M52, to light, P.E. Bragg, viii.1993.

This species appears to be the same as the Creobroter sp. illustrated by Helmkampf et al. (2007: Plate 1, middle-right).

Deroplatys desiccata Westwood, 1839

ऽ PEB-M13, ð̊ PEB-M14, P.E. Bragg, viii.1993.

Specimen PEB-M14 is illustrated in Bragg, 1997b: fig 6, \& Bragg in Prete et al., 2000: fig. $2.3 \mathrm{~b}$.

Euchomenella heteroptera (De Haan, 1842)

§ PEB-M11 to light, P.E. Bragg, viii.1993.

Hierodula gracilicollis Stål, 1877 (Figs. 12A \& 13)

ô PEB-M32, ô PEB-M33 to light, P.E. Bragg, viii.1993.

The genitalia agrees with the illustration of Schwarz \& Roy (2019: fig. 23f), and with Hierodula sp. 3 (Helmkampf et al., 2007: plate 1 top left), and is compatible with the female holotype illustrated by Sjöstedt (1930: fig. 10.4).

Hierodula sp. H5 (Figs. 12D \& 16)

ઈิ PEB-M44, § PEB-M45 to light, P.E. Bragg, viii.1993.

The genitalia agree with the "H. venosa (Olivier, 1792)" of Schwarz \& Roy (2019 fig. 23g).

Humbertiella ocularis Saussure, 1872

§ PEB-M124 P.E. Bragg, viii.1993.

Statilia maculata (Thunberg, 1784)

ô PEB-M47 to light, P.E. Bragg, viii.1993.

Theopompa tosta Stål, 1877

đ̊ PEB-M53, đ̊ PEB-M54, to light, P.E. Bragg, viii.1993. 


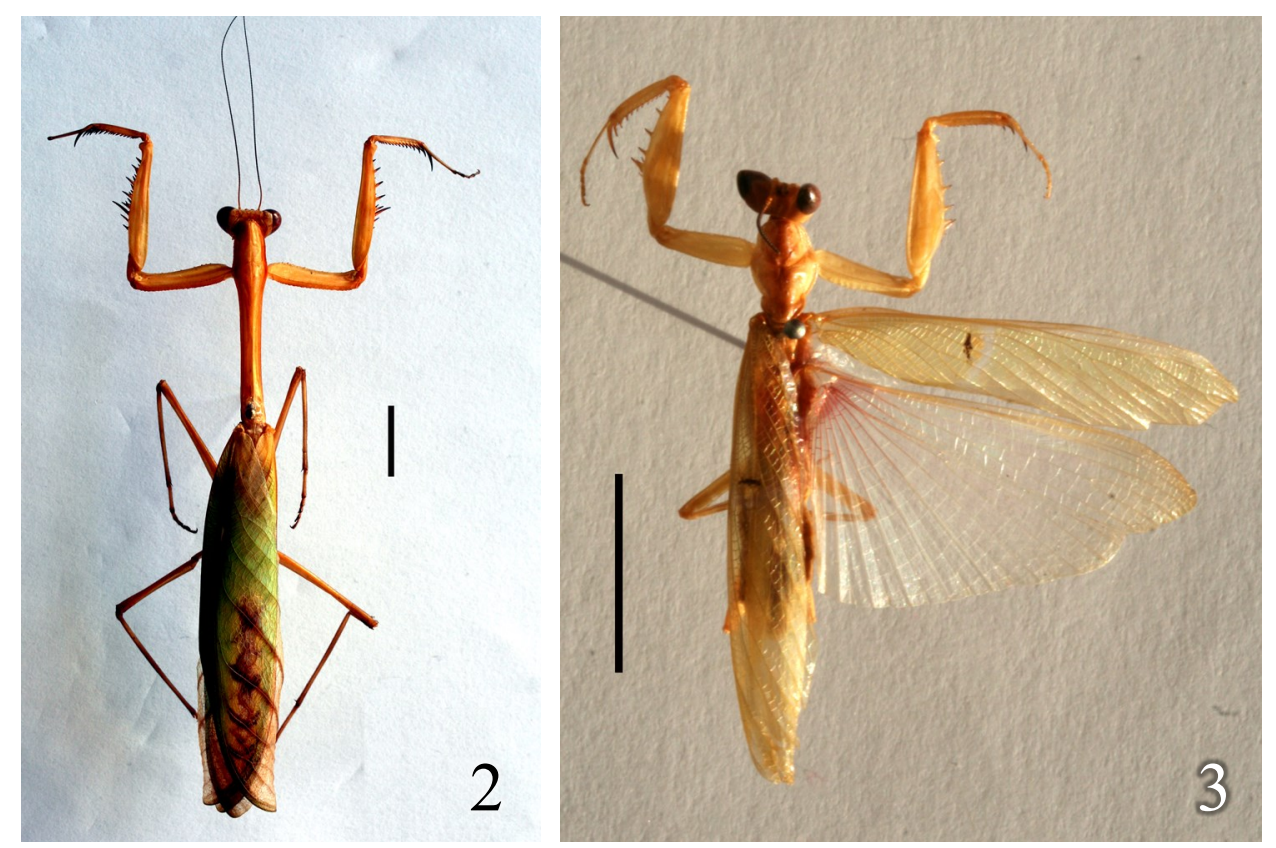

Figures 2-3. Dorsal view of: 2. Camelomantis giraffa (Giglio-Tos, 1912) § PEB-M43, 3. Creobroter episcopalis Stål, $1877 \precsim$ PEB-M52. Scale: $1 \mathrm{~cm}$.

\section{Kelembenkari, Base camp (113 $\left.54^{\circ} 30^{\prime \prime E} 02^{\circ} 19^{\prime} 02^{\prime \prime S}\right)$.}

Acromantis moultoni Giglio-Tos, 1915

§ PEB-M78 to light. code M5, P. Jenkins, viii.1994.

Catestiasula moultoni Giglio-Tos, 1915

ㅇ PEB-M21 P. Jenkins, 23.viii.1993.

Creobroter episcopalis Stål, 1877

§̂ PEB-M76 to light code M3, P. Jenkins, viii.1994.

Deroplatys truncata (Guérin, 1843)

§ิ PEB-M19 P. Jenkins, 20.viii.1993.

Euchomenella heteroptera (De Haan, 1842)

○ PEB-M20, ð PEB-M73 P. Jenkins, 20.viii.1993.

§̂ PEB-M80 to light, code M7, P. Jenkins, viii. 1994.

Haania sp. (Figs. 4-5)

Photographic record only, P.E. Bragg, viii.1993. The specimen was out of reach and was photographed at arms length, with the focus distance estimated, consequently the 
photograph is of relatively low quality so identification to species level is not practicable. The photograph and enlargement are included here to illustrate how well the insect is camouflaged.
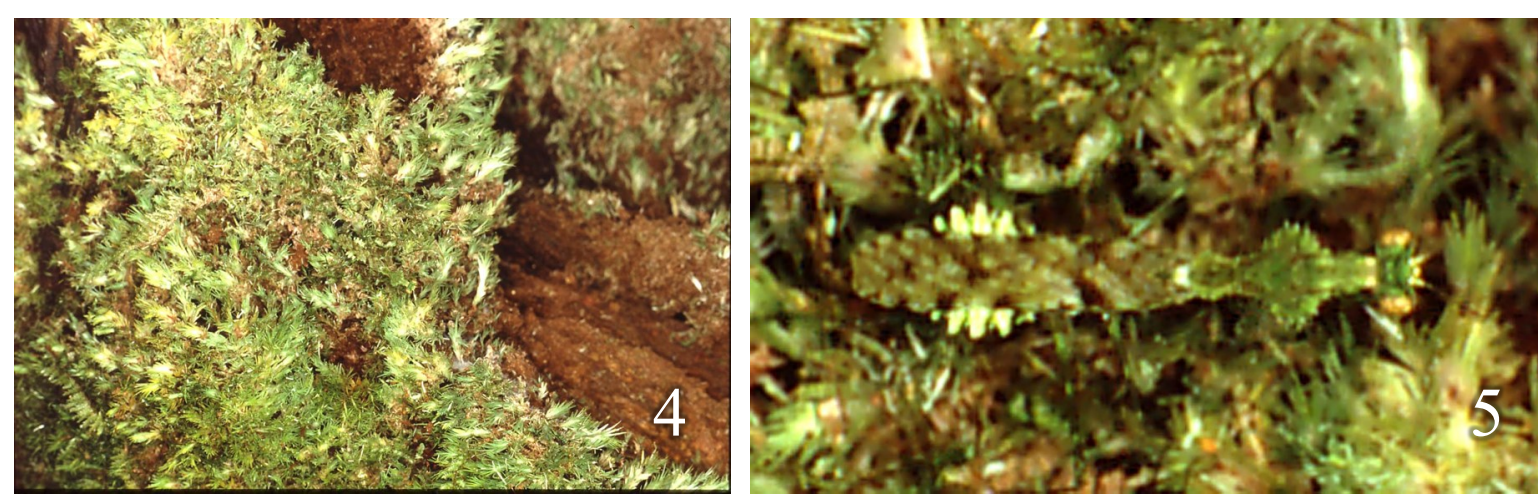

Figures 4-5. Haania sp.: 4. on moss covered tree trunk, 5. the same photograph enlarged and rotated.

Hierodula sp. H3 (Figs. 12B \& 14)

ô PEB-M74 code M1, P. Jenkins, ix.1994.

The genitalia of this specimen agree with the "H. vitrea (Stoll, 1813)" of Schwarz \& Roy (2019: 23h). There is no stigma present on the elytra of this specimen; all other specimens of this species in my collection possess a white stigma.

Hierodula sp. H4 (Figs. 12C \& 15)

ऽ PEB-M40 P.E. Bragg, viii.1993.

Humbertiella ocularis Saussure, 1872

đ̊ PEB-M79 to light. code M6, P. Jenkins, viii.1994.

Odontomantis micantula Beier, 1956 (Figs. 7A, 7B \& 8-11)

§ PEB-M28 P. Jenkins 20.viii.1993.

q PEB-M29, ठ̊ PEB-M30, P.E. Bragg, viii.1993.

O PEB-M77 code M4. P. Jenkins, viii.1994.

đิ PEB-M81, ô PEB-M82, code M8 P. Jenkins, 06.ix.1994.

Specimen, PEB-M29 was illustrated in Bragg, 1997b: fig 4, and Bragg in Prete et al., 2000, fig 2.3A, under the name Odontomantis micans. 
Sceptuchus simplex Hebard, 1920 (Fig. 6)

ô PEB-M31 P. Jenkins 20.viii.1993.

Theopompa borneana Giglio-Tos, 1917

ô PEB-M72, P. Jenkins, 20.viii.1993.

Theopompa tosta Stål, 1877

ô PEB-M71, P. Jenkins, 20.viii.1993.

§ PEB-M75, to light. code M2, P. Jenkins, viii.1994.

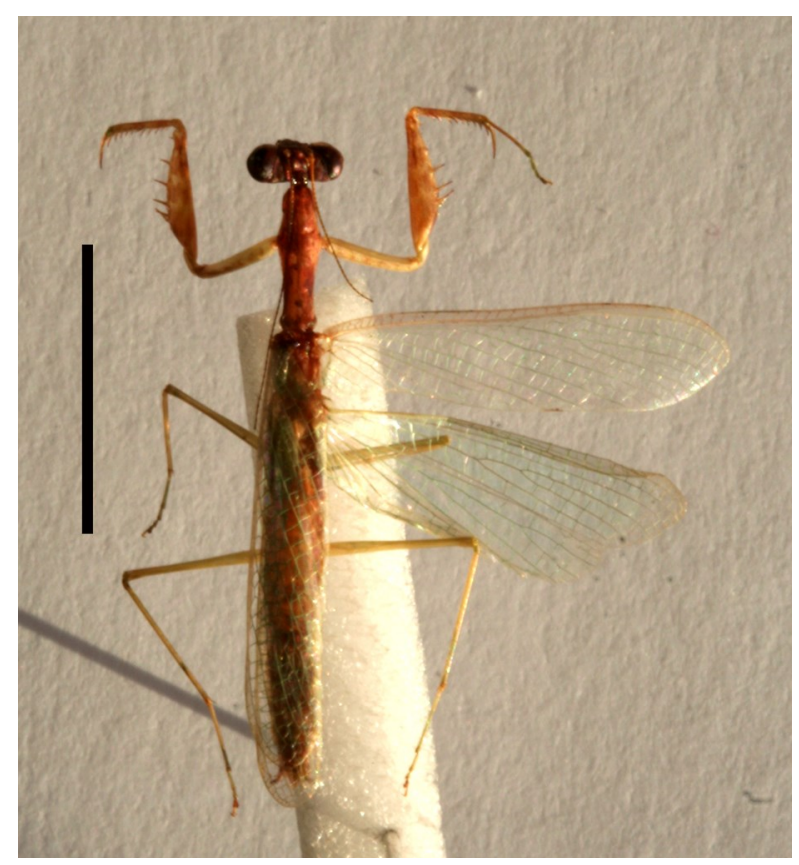

Figure 6. Dorsal view of Sceptuchus simplex Hebard, 1920 ¿ै PEB-M31. Scale: $1 \mathrm{~cm}$.

Kelembenkari, Bukit Jak (11352’34”E 02²3’43”S).

Acromantis moultoni Giglio-Tos, 1915

† PEB-M23 to light, P.E. Bragg, 09.viii.1993.

Theopompa borneana Giglio-Tos, 1917

ô PEB-M22 to light, P.E. Bragg, 09.viii.1993.

Tropidomantis tenera (Stål, 1860)

q PEB-M24, $q$ PEB-M25, $q$ PEB-M26 to light, P.E. Bragg, 09.viii.1993. 
Table 1. Elytra / pronotum ratios for Hierodula and Hymenopus specimens and Stoll's drawings

\begin{tabular}{lll}
\hline Species & Elytra / Pronotum & Notes \\
\hline Hierodula sp. H3 & 2.37 & $\mathrm{n}=8$. Range $=2.19-2.45$. \\
Hierodula sp. H4 & 2.21 & $\mathrm{n}=1$. \\
Hierodula sp. H5 & 2.28 & $\mathrm{n}=6$. Range $=2.22-2.32$. \\
Stoll - plate 5 figure 19 & 2.6 & Hierodula vitrea (Stoll) \\
Stoll - plate 15 figure 60 & 1.8 & Hierodula venosa (Olivier) \\
Hymenopus coronatus + specimens & 3.98 & $\mathrm{n}=3$. Range $=3.86-4.01$. \\
Stoll - plate 11 figure 44 & 3.0 & Hymenopus coronatus (Olivier) \\
\hline
\end{tabular}

\section{DISCUSSION}

The last published record for a significant number of mantids from Kalimantan was based on material in Museum Zoologicum Bogoriense (Beier, 1958). Beier recorded 82+ specimens of 21 species, the exact number of specimens from Borneo is unclear as material from other islands was included. Since then records for Kalimantan have mostly been limited to mention of a few specimens included as part of a taxonomic revision of a small groups e.g. the Theopompa and Humbertiella specimens listed above (Bragg, 2010), and most recently a specimen of Astyliasula which was collected on the Borneo-Expedition of Dr. Nieuwenhuis in 1894 (Schwarz \& Shcherbakov, 2017). Other genera with post-1958 records from Kalimantan include one species of Euchomenella, (Roy, 2001), one species of Amorphoscelis (Roy, 1967, 2011); one species of Pachymantis (Roy, 2013), two species of Metallyticus (Wieland, 2008); one species of Deroplatys (Delfosse, 2009); in their checklist of Bornean species, Schwarz \& Konopik (2014) also record localities from museum specimens for: one species of Theopropus, two of Theopompa, and three additional Deroplatys. In recent years there has been an explosion in interest in Bornean mantids, resulting in several small collecting expeditions, but all those reported: Helmkampf et al. (2007), Ling et al. (2013), Schwarz \& Konopik (2014), Nazirah et al. (2015), have been in Sabah or Sarawak.

The material recorded here comprises 41 specimens of 20 different species which were collected in two strikingly different habitats: peatswamp forest and hill forest. No assessment has been made of the mantid fauna in different habitats in Borneo. The results here show only four species were found in both the peat swamp near Palangkaraya and the 
hill forest at Ratu Miri. The Bornean mantids in my personal collection were all collected in the same casual manner, i.e. while searching for phasmids, so some comparison can be made. Of the four species found in both areas, E. heteroptera, T. tosta and H. ocularis are respectively the first, third, and sixth most common species in my personal collection; the other species, $C$. episcopalis, is one which I have not collected elsewhere. The most abundant species in this small collection is $O$. micantula which is represented by six specimens. The small number of specimens found: 26 (14 species) at Kelembenkari, and 15 (10 species) at Ratu Miri, is too few to reach any conclusion regarding possible differences in the mantid fauna in peat swamp and hill forest; it does however, suggest that further investigation is warranted.

Efforts to confirm the identity of the Hierodula and Odontomantis specimens led to the finding that both genera suffer from significant problems due to the inadequate description of the species, lack of suitable illustrations, and conflicting subjective synonyms. In both cases the problems with the Bornean species can only be resolved by redescribing the type specimens (if they can be located). Copies of the original publications have been examined for the first descriptions and for all subsequent records of Bornean Odontomantis. Some of the issues are discussed below.

\section{Notes on Odontomantis Saussure, 1871}

The type species is Acromantis javana Saussure, 1870. Saussure (1871: 32) established Odontomantis as a subgenus of Micromantis Saussure, 1870 with only one species, O. (M.) javana (Saussure, 1870), included; Kirby (1904: 223) also clearly stated javana to be the type species. Ehrmann (2002: 243) incorrectly gives the type species as O. planiceps (De Haan, 1842), presumably because javana had been synonymized with planiceps.

Three species of Odontomantis are currently treated as Bornean. However, there are very few definite records for any of the species and it is possible that some of these records are misidentifications; in particular the subjective synonym of planiceps and javana seems doubtful. Part of the problem with the genus, as with many genera, is the very brief nature of early descriptions and a lack of suitable illustrations. The distinctions between the earlier species of Odontomantis often relies on the coloration; this presents potential problems due to possible discoloration of specimens which may have been sun-dried, compared to specimens dried in the dark. Illustrations by De Haan (1842) were hand-colored, often by students, and have been found to vary (Bragg, 2001: 358); this opens the possibility that different authors worked from slightly different coloring on the illustrations of De Haan's 
species. The only illustration De Haan provided is a fairly small habitus drawing which is of limited value for distinguishing between similar species; Saussure's (1871, plate 4 figure 11) illustration of javana is at a larger scale and more reliable.

The key below to females of the known Bornean members of the genus is based on the original description and illustration of $O$. rhyssa Werner, 1930 (p. 7, pl. 3.1), Beier's 1956 comments and my own material of $O$. micantula, and the illustration of $O$. planiceps (De Haan, 1842: plate 17, fig 10).

\section{Key to female Bornean Odontomantis species}

1. Pronotum granulose. Pronotum sides (at least in the female) not straight, clearly wider at the junction of the prozone $\&$ metazone (Fig. 7E) O. rhyssa Werner, 1930

- Dorsal surface of pronotum smooth (although the margin may be cranulate). Sides of the pronotum straight or with only a smooth curve, not significantly wider at the prozonemetazone junction (Figs 7A-7D) 2

2. Pronotum wide, only just twice as long as wide (figs 7A \& 7B); frontal plate of head almost triangular, about half as high as wide (Fig. 10) ...... O. micantula Beier, 1956

- Pronotum more slender, distinctly more than twice as long as wide (Fig. 7C)
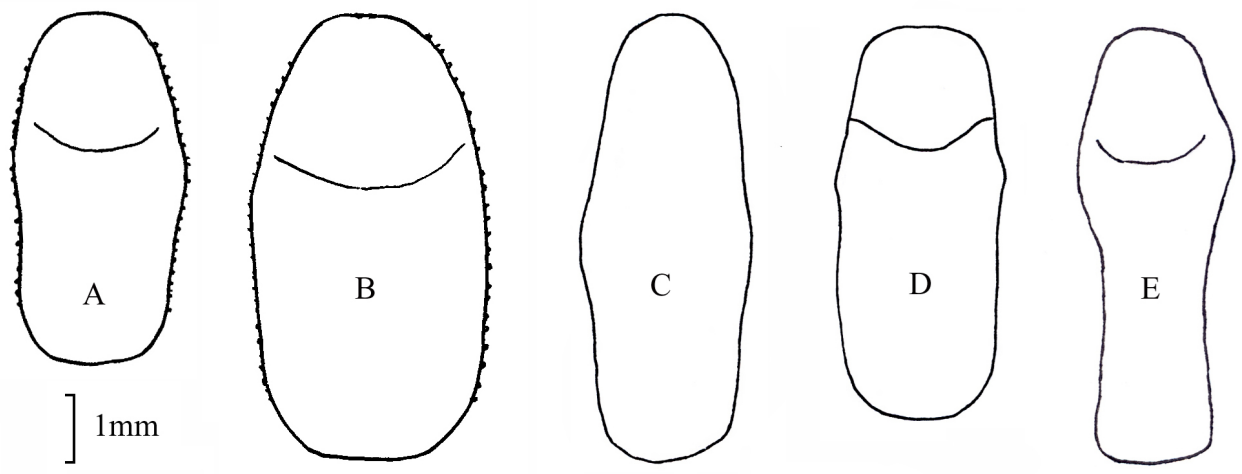

Figure 7. Pronota of Odontomantis spp. - A. $\bigcirc$ O. micantula, B. $\uparrow$ O. micantula, C. $\uparrow$ O. planiceps, D. + O. javana, E. + O. rhyssa. 


\section{Odontomantis micantula Beier, 1956}

Odontomantis micans [Not micans Saussure] Giglio-Tos, 1927: 542 [in part]; Werner, 1930: 7; Beier, 1934: 16 [in part]; Beier, 1937: 180; Bragg, 1997b: fig 4 (q); Bragg in Prete et al., 2000, fig 2.3A (); Ehrmann, 2002: 244 [in part].

Odontomantis micantula Beier, 1956: 39; Schwartz \& Konopik, 2014: 141.

Syntypes: $1 \overbrace{}^{\lambda}, 1$ ㅇ SARAWAK, foot of Mt. Dulit, junction of rivers Tinjar and Lejok, 19.ix.1932 \& 5.x.1932 (BMNH).
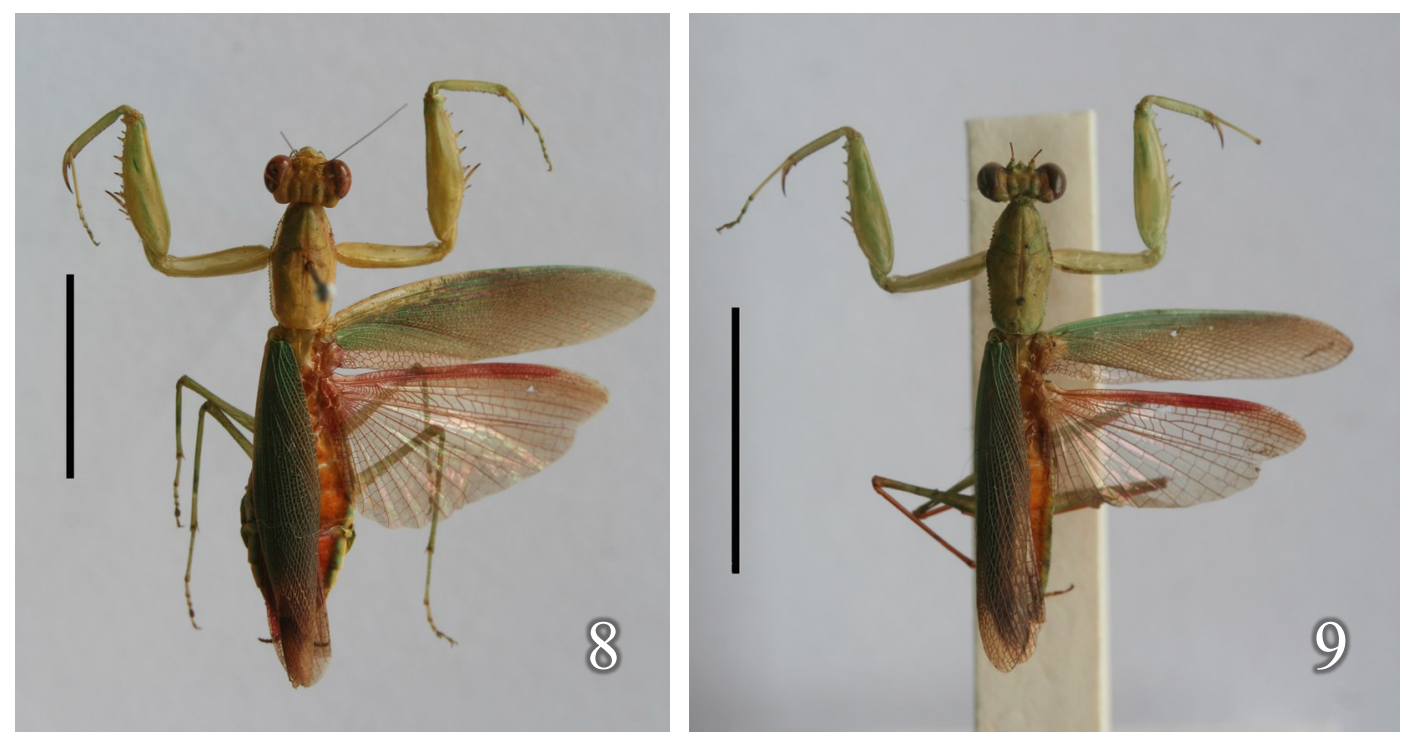

Figures 8-9. Dorsal view of Odontomantis micantula Beier, 1956: 8. ํ PEB-M29, 9. ^઼ PEB-M28. Scale: $1 \mathrm{~cm}$.

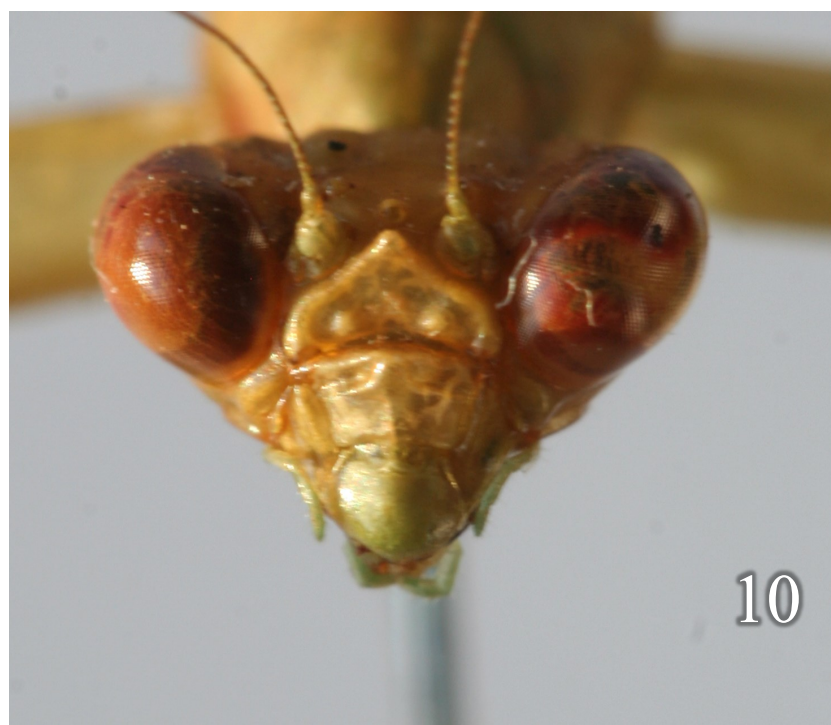

Figures 10-11. Odontomantis micantula Beier, 1956 subgenital plate and genitalia $\overparen{\jmath}$ PEB-M81. Scale: $1 \mathrm{~mm}$.

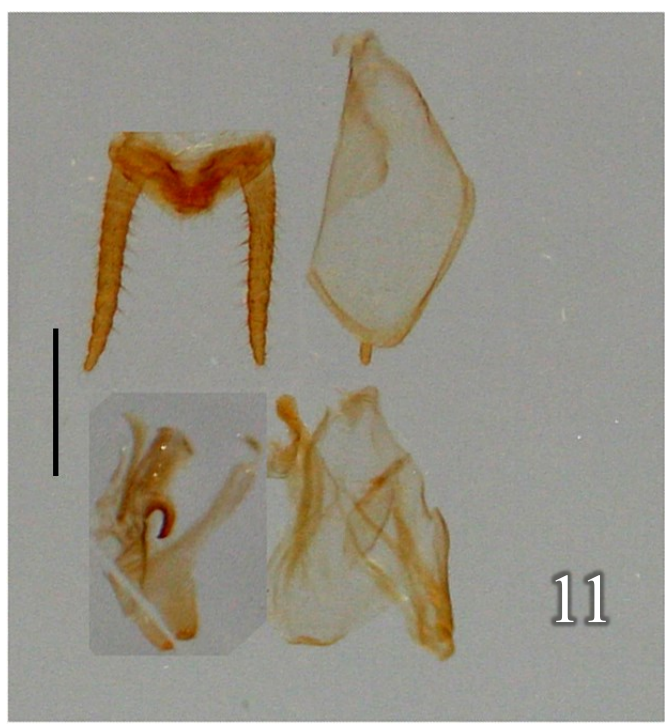

10. head of $\bigcirc$ PEB-M29, 11. cerci, 
Schwarz \& Konopik (2014: 141) recently highlighted that Odontomantis micantula Beier, 1956 had been overlooked by all subsequent authors. Beier (1956: 38-39) in his paper on mantids from Ceylon (now Sri Lanka) blames Giglio-Tos for confusing two species as he was the first to include Borneo as a locality for "micans", along with Sumatra and Mentawai Island. Beier declared the previous records of "Odontomantis micans (Saussure, 1871)" from "Malacca and the Sunda Islands" to be in error and said "Ich schlage für sie den Namen micantula vor." ["I suggest the name micantula for them"]. Clearly, Beier considered he was re-naming the "Malacca and Sunda Islands" species rather than describing it as new. Beier did not designate any type material, or mention any specimens: he just gave brief distinction between micans and micantula. This presents a problem regarding the type material. He states the name applies to all "micans" from Malacca and the Sunda Islands. As he did not specify the type material, any specimens which he is known to have examined from the Sunda Islands should be regarded as syntypes.

I have only been able to find one publication by Beier in which he records locality data for $O$. micans from the Sunda Islands (Beier, 1937: 180); these two specimens from Borneo must therefore be regarded as the syntypes of micantula. Although Beier may well have examined other specimens of "micans" from "Malacca and the Sunda Islands" in the absence of any published evidence, the two specimens recorded in 1937 should be regarded as the only syntypes. The two specimens from his 1937 paper are in the Natural History Museum, London $(\mathrm{BMNH})$. His 1956 paper states the material he was working on from Ceylon is in the Naturhistorischen Museum, Basel (NHMB) but he gives no indication of any specimens of micantula in NHMB. The only other pre-1956 record for micans from Borneo that I have found is for one female recorded by Werner (1930: 7) from 1700m on Mt. Tibang, collected by Mjöberg; this I exclude as a syntype as there is no evidence that Beier had seen it.

The material I have from Kelembenkari keys out as micans using Giglio-Tos's key (1927: 541) but is clearly different to the illustrations of Odontomantis micans (Saussure, 1871) presented by Beier (1956: fig 1b). My material agrees with the differences mentioned by Beier for micantula, most notably the shape of the frontal shield (fig. 10), therefore I am able to confirm Beier was correct in declaring the Bornean "micans" to be a different species.

Schwarz \& Konopik (2014) recorded specimens from Sarawak: Marudi, Sabah: Crocker Range, Mesilau. 
Table 2. Measurements of Odontomantis micantula

\begin{tabular}{lll}
\hline Odontomantis micantula & Females $(\mathbf{m m})$ & Males $(\mathbf{m m})$ \\
\hline Total length & $23.8-24.2$ & $16.2-18.2$ \\
Pronotum & 6.1 & $4.4-4.7$ \\
Prozone & 2.5 & 1.7 \\
Metazone & $3.6-3.7$ & $2.7-3.0$ \\
Pronotum maximum width & 3.1 & $2.2-2.5$ \\
Elytra & $17.6-18.2$ & $11.7-12.9$ \\
Fore coxa & 5.4 & $3.4-4.0$ \\
Fore femora & 6.9 & $4.5-5.1$ \\
Mid femora & 5.6 & $3.9-4.5$ \\
Hind femora & 6.3 & $4.4-5.1$ \\
\hline
\end{tabular}

\section{O. planiceps (De Haan, 1842)}

Mantis (Oxypillus) planiceps De Haan, 1842: 88, plate 17, fig 10 (ㅇ) [not the described "male" or fig $11(\hat{\jmath})]$.

Micromantis planiceps (De Haan); Saussure, 1871: 31 [ㅇ not $\lesssim$ ]

Odontomantis planiceps (De Haan); Kirby, 1904: 223 [Kirby also states only fig 10, not fig 11]; Giglio-Tos, 1927: 542; Werner, 1933: 270; Beier, 1934: 16, plate 2 fig. 9 (ㅇ); Ehrmann, 2002: 244; Schwarz \& Konopik, 2014: 140; Shcherbakov et al., 2016: 137, fig. $6 \mathrm{~F}$ ( $q$ pronotum).

Acromantis javana Saussure, 1870: 230. Synonymized by Giglio-Tos, 1927: 542 [not Acromantis javana Giglio-Tos, 1915]

Micromantis (Odontomantis) javana; Saussure, 1871: 32, plate 4 fig, 11 (q).

Odontomantis javana; Stå1, 1877: 87; Kirby, 1904: 223.

Odontomantis javana javana; Hebard, 1920: 76.

De Haan described planiceps and illustrated the female (plate 17, fig 10) and the "male" (plate 17, fig 11). The "two sexes" of planiceps have long been recognized as different species (Saussure, 1871: 32; Kirby, 1904: 223), with the illustrated female (fig. 10) being treated as the Lectotype (although not formally designated), and the "male" being treated as a female Tropidomantis tenera Stål, 1858 (Kirby, 1904: 227). A reference to Mantis (Oxypillus) planiceps by Giebel (1861: 112) was excluded by Kirby who considered Giebel was describing a different species; Giebel did not give any locality data. Although 
Kirby did not include Giebel's reference under his entry for T. tenera, Kirby included Giebel in the same brackets he used to exclude De Haan's figure 11 from planiceps, so it is reasonable to assume Kirby considered Giebel's record to relate to T. tenera.

To ensure stability of the name planiceps a Lectotype needs to be selected; it should be the species illustrated in De Haan's plate 17, figure 10, and not the species in figure 11. Unfortunately, due to the current Covid-19 pandemic and resulting museum closures, I am unable to check the specimen details, and when a Lectotype is selected a redescription would be essential. The number of specimens available to De Haan is not stated and his use of "de mannetjes" (the males) and "de wijfjes" (the females) in the Dutch description does not mean he had more than one of each: De Haan could be using the plural in the sense of "in the females of this species" rather than "the females I have in front of me". This usage would be consistent with his usage of "de wijfjes" when discussing Phasma galacpterum (De Haan, 1842: 127), a species for which only one of the syntypes is female (Bragg, 1996: 111). Some differences in coloration, or even pattern on the wings should not exclude a specimen from being selected as the illustrated specimen in view of variations that are known occur between different copies of De Haan's book.

Ehrmann's (2002: 244) entry for planiceps contains several errors. Ehrmann lists the types as "Holotypus $\precsim$ RMNH, Allotypus $q$ RMNH. Locus typicus: Java ( $₫)$, Borneo ( $q)$ ", but later (Ehrmann, 2002: 362) correctly lists De Haan's “male” (fig. 11) as a synonym of $T$. tenera. Clearly neither specimen can be a holotype as De Haan did not designate a holotype and had at least two specimens. It is not clear why Ehrmann considered the female to be from Borneo, and the "male" from Java: De Haan does not specify which specimen is from which island. Ehrmann then lists Acromantis javana Giglio-Tos, 1915 as a synonym, but indicating that it was "In Saussure, 1870: 230", then repeats the error with Saussure's 1871 and Stål's 1877 records. Acromantis javana Giglio-Tos, 1915 is an invalid name because it is a primary homonym which was replaced with the name Acromantis lilii Werner, 1922 (Werner, 1922: 155).

Stål (1877) records O. javana from Java. Hebard (1920: 76) recorded O. javana javana (Saussure, 1870) from Labuan, Sandakan, and also from Palawan. Hebard (1920: 77) commented on the brevity of the original description of $O$. euphrosyne Stål, 1877 and said he considered it "represents a geographic race of javana", recording it from the Philippines as Odontomantis javana euphrosyne Stål. Giglio-Tos (1927: 543), Beier (1934: 16), and 
Ehrmann (2002: 243) all overlooked this and listed euphrosyne as a distinct species. GiglioTos (1927: 543) said he thought euphrosyne might be the same species as "micans" (i.e. what is now micantula).

The female described by De Haan could be from either Borneo or Java; the type material might clarify this, but often De Haan's labels were not on the actual specimens, they were placed above or below the specimens for display purposes. Hebard's records are for javana, and are only treated as planiceps due to Giglio-Tos subsequently synonymising the two species. The synonymy of javana and planiceps appears doubtful based on the illustrations of De Haan and Saussure (see figs 7C-D). Additionally, Saussure (1871: 32) clearly states that javana differs from planiceps by having a broader prothorax. It seems unlikely that javana and planiceps are the same species. The pronotum illustrations of Beier (1934, plate 2 fig. 9), and Shcherbakov et al. (2016, fig 6F), do not agree with De Haan's: they are much wider, closer to that of Saussure's javana. Neither Beier, nor Shcherbakov et al., give any data for their material.

The only clear distribution records for planiceps in Borneo are those of Werner (1933) and Schwarz \& Konopik (2014). Werner recorded specimens from West Java, and specimens from the Central East Borneo Expedition, and from Long Petak, collected by H.C. Siebers. Schwarz \& Konopik recorded material from Kuching, Matang, Santubong, Kilingkang and Sorinsim. All identifications made while planiceps and javana are considered synonyms may need checking once the Lectotype of planiceps has been redescribed and the synonym reassessed.

\section{O. rhyssa Werner, 1930}

Odontomantis rhyssa Werner, 1930: 7, plate 3 figure 1 (); Sjöstedt, 1930: 14; Beier, 1934: 16; Beier, 1937: 180; Ehrmann, 2002: 244; Schwarz \& Konopik, 2014: 141; Shcherbakov et al., 2016: 136-137, figs 6G (pronotum) \& 9B (elytron).

The original description is based on one female from "Borneo" collected by Eric Mjöberg. Beier records " $1 \delta$, $1 q$ foot of Mt Dulit, junction of rivers Tinjar and Lejok, 22.viii.1932 \& Mt. Dulit, 4,000ft., Moss forest, 14.x.1932”. Beier (1937) comments that this is an easily recognizable species because of the granulose pronotum. Shcherbakov et al. (2016) illustrate the species but do not give any data about their specimen. 


\section{Notes on Hierodula Burmeister, 1838}

The genus Hierodula is the largest genus of mantids, with 104 species listed by Ehrmann (2002). Subsequently a few new species have been described and a few others have been transferred elsewhere, but the genus remains the largest. The number of species from Borneo is unclear. Schwarz \& Konopik (2014: 149) stated "Sixteen species currently known from Borneo" but listed only 12, with two further species listed in the "Doubtful species without confirmed Bornean records"; I understand the count of 16 should have been corrected following some taxonomic changes (Schwarz, pers. com. 2021). Ephierodula heteroptera (Werner, 1906) was recently removed from Hierodula by Schwarz \& Roy (2018), leaving eleven Bornean species, of which six are endemic. However the majority of Bornean species are so poorly described that it is impossible to identify them from the descriptions alone, the issue is further complicated by historical issues surrounding the oldest two species. Even with relatively recently described species, the distinction given between species often relies on comparative statements: for example, Werner (1933) described seven new species of Hierodula, three from Borneo, and almost every description relates it to another one or two species which he was describing as new in the same paper: none are illustrated. The stated distinction between species may often rely on the color of spines on the fore femora, or the presence of spots on the fore femora: both these characters seem to be variable within species. Brunner (1898) illustrated the femoral spots for three of his new Bornean species but did not illustrate the rest of the insects. Werner illustrated the pronotum of one species (1930, plate 1, fig 3), but again the species is defined by spots on the femora. Descriptions of new species prior to about 1840 were particularly brief and as a consequence, many differing subjective synonyms have been published over the past 200 years.

Stoll (1787) described the first Bornean mantids that are now in the genus Hierodula. Stoll's publication on mantids and phasmids was published in two parts; the first part (pages 1-56 and plates 1-18) was published in either 1787, or 1788; the title page, and remaining pages and plates, including the index were published posthumously in 1813. I have been unable to confirm the publication date for the first part: here I use the date given by Lichtenstein (1802: 2), but Woodward (1915: 2028) gives 1788 as the date; however, it is possible that the copy cataloged by Woodward was printed in 1787 but did not reach the UK until 1788. Binomial names were not used until the index which was published in 1813; all the mantids were described in the genus Mantis. In the intervening years Olivier (1792) and Lichtenstein (1796) had named several of the illustrated phasmids and mantids so many of 
Stoll's names became junior objective synonyms (Bragg, 1995). The current location of many of the specimens illustrated by Stoll is unknown, however, I located some of his phasmids in Leiden Museum (Bragg, 1996) and it is very likely that some of his mantids are also in Leiden.

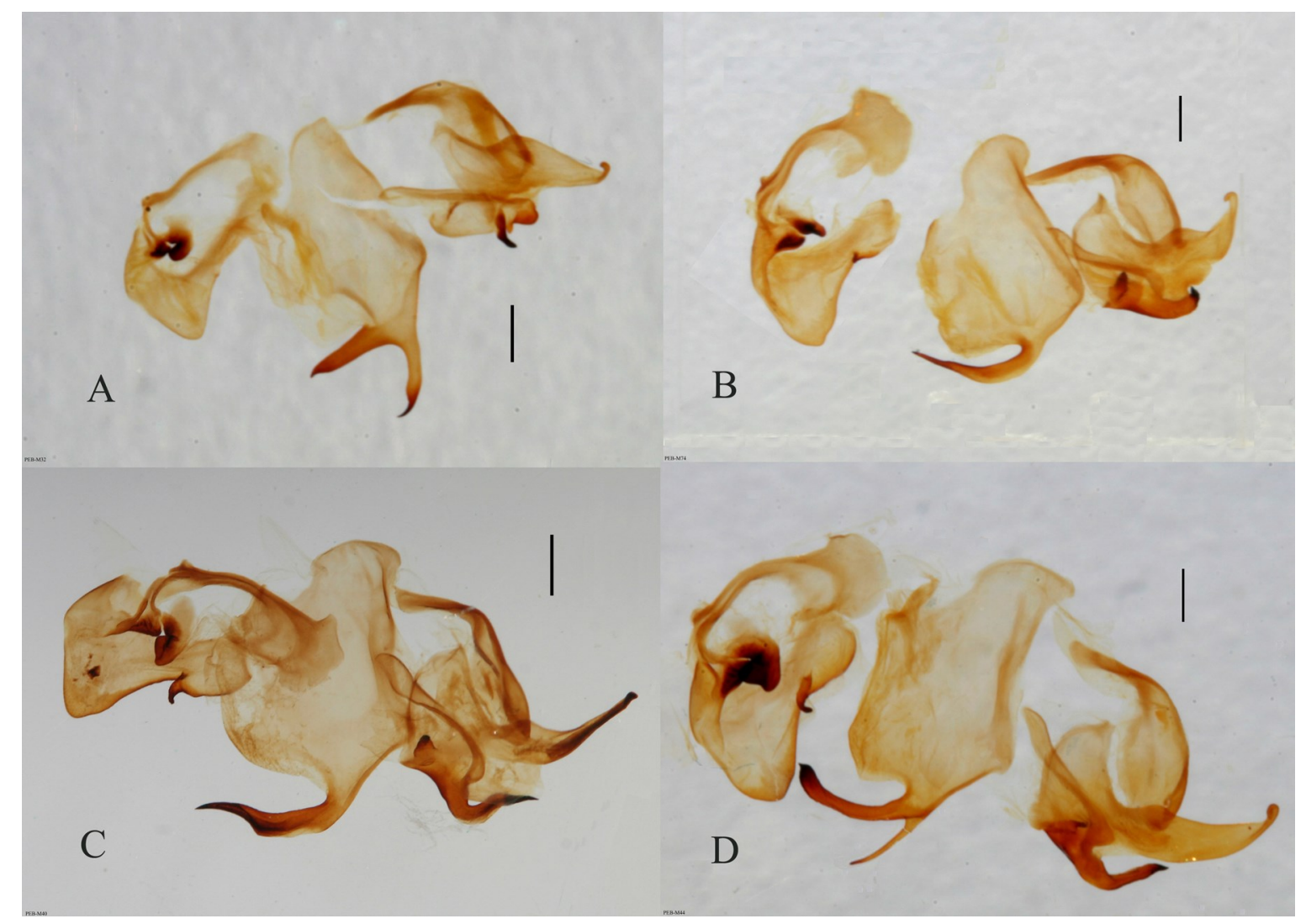

Figure 12. Hierodula spp. ổ genitalia - A. H. gracilicollis Stål, 1877, B. H3, C. H4, D. H5. Scale: $1 \mathrm{~mm}$.

Three of Stoll's species are currently in the genus Hierodula. Two of these: H. venosa (Olivier, 1792) $[=$ M. punctata Stoll, 1813; = M. conspurcata Lichtenstein, 1796 - both objective synonyms] and H. unimaculata (Olivier, 1792) [= M. notata Stoll, 1813 objective synonym] were described from Tranquebar on the East coast of India. Hierodula vitrea (Stoll, 1813) was described from "Surinam" but this was considered unlikely by Kirby (1904: 246) and subsequent authors. Identification of Bornean Hierodula tends to be based on the keys and brief descriptions provided by Giglio-Tos (1927). Currently, vitrea is treated as Bornean (Schwarz \& Konopik, 2014) but the status of H. vitrea is very confused because of differing subjective synonyms published by various authors, and the questions 
surrounding the origin of Stoll's specimen. There is even some doubt about the generic placement of vitrea: Stoll's illustration (plate 5, figure 19) was treated as Mantis oratoria Fabricius, 1775 by Lichtenstein (1876: 80; 1802: 28), a species which has subsequently been treated as a synonym of Mantis religiosa Linnaeus, 1758 (e.g. Kirby, 1904: 250; Ehrmann, 2002: 216). Holthuysen's collection was in Hamburg when Lichtenstein was working on it (Lichtenstein, 1802: 1 \& 3) but, although Lichtenstein had certainly seen the type specimen of venosa, it is not clear if he had seen the specimen of vitrea as this was not mentioned as being in L.F. Holthuysen's collection. Hebard (1920: 56) considered vitrea and venosa could be the male and female of one species, and said of the confused synonymy in Hierodula "Consequently many features usually considered of specific diagnostic value, will probably be found worthless for the species under consideration"; Beier (1935: 81) and Ehrmann (2002: 184) both listed vitrea as a synonym of venosa.

Hierodula hybrida Burmeister, 1838 was recorded from Borneo by De Haan (1842: 68). Saussure (1871:76) synonymized vitrea Stoll and $H$. hybrida: a synonym rejected by Kirby (1904: 246), but reinstated by subsequent authors. Hierodula venosa was synonymized with hybrida and vitrea by Beier (1935: 81). In addition, H. athene Rehn, 1909 described from Sumatra, has been synonymized with venosa by Beier (1935: 81). With so many differing opinions on the synonymy the examination of the type material is essential. The holotype of hybrida is present in Berlin Museum (Ehrmann, 2002: 184), however, it is a female so is unlikely to be of much use for distinguishing species because the only reliable method of distinguishing species at present is by comparing the male genitalia. The locations of the type specimens of vitrea and venosa, are unknown; I am not aware of any attempts to locate them.

Stoll (1787 \& 1813), Olivier (1792), and Lichtenstein (1796 \& 1802), did not give any measurements of specimens. The only potentially useful measurements that can be taken from the drawings are the lengths of the pronotum (p) and elytra (e). Measurements taken from my material and Stoll's drawings (Table 1) have proven to be of no assistance in identifying the Hierodula; the Hymenopus results show proportions taken from Stoll's drawings can differ from reality by at least $30 \%$. This is a result of the drawings having been made to show them in a life-like perspective, rather than inaccuracies in the drawings. However, whilst the drawings are good representations of the species, they are not scientific illustrations and consequently cannot be used to determine accurate proportions of species.

The six specimens of Hierodula recorded in this paper represent four species. The two specimens of $H$. gracilicollis Stål, 1877 from Ratu Miri agree with both the illustration of 
"Hierodula Spec. 3" (Helmkampf et al. 2007: Plate 1, top left), and the genitalia illustrated by Schwarz \& Roy (2019: fig 23f); the slender, smooth pronotum of these males is in agreement with Stål's female holotype (Sjöstedt, 1930: fig. 10.4). The other three species (H3, H4, \& H5) all have the general form of venosa - vitrea - hybrida - athene, and of a number of other species from the Sunda Islands. Species H3 agrees with the genitalia illustrations of Schwarz \& Roy's H. vitrea (the illustration here (Fig. 12B) appears slightly different because the genitalia were mounted using slide spacers, consequently the genitalia have retained some of the original three-dimensional shape: viewing the slide at an angle shows it to be identical). Species H5 (Fig. 12D) agrees with Schwarz \& Roy's H. venosa. However, the identifications as venosa and vitrea are based on the interpretation of GiglioTos (1927). In view of the number of similar species in the region, and the stated localities of Stoll's specimens (Surinam and India), and the absence of type material of vitrea and venosa, these names are little more than speculative and I regard these two names as nomen dubia. It is quite likely examination of the genitalia of Brunner's and Werner's Bornean types will provide reliable names for these species.
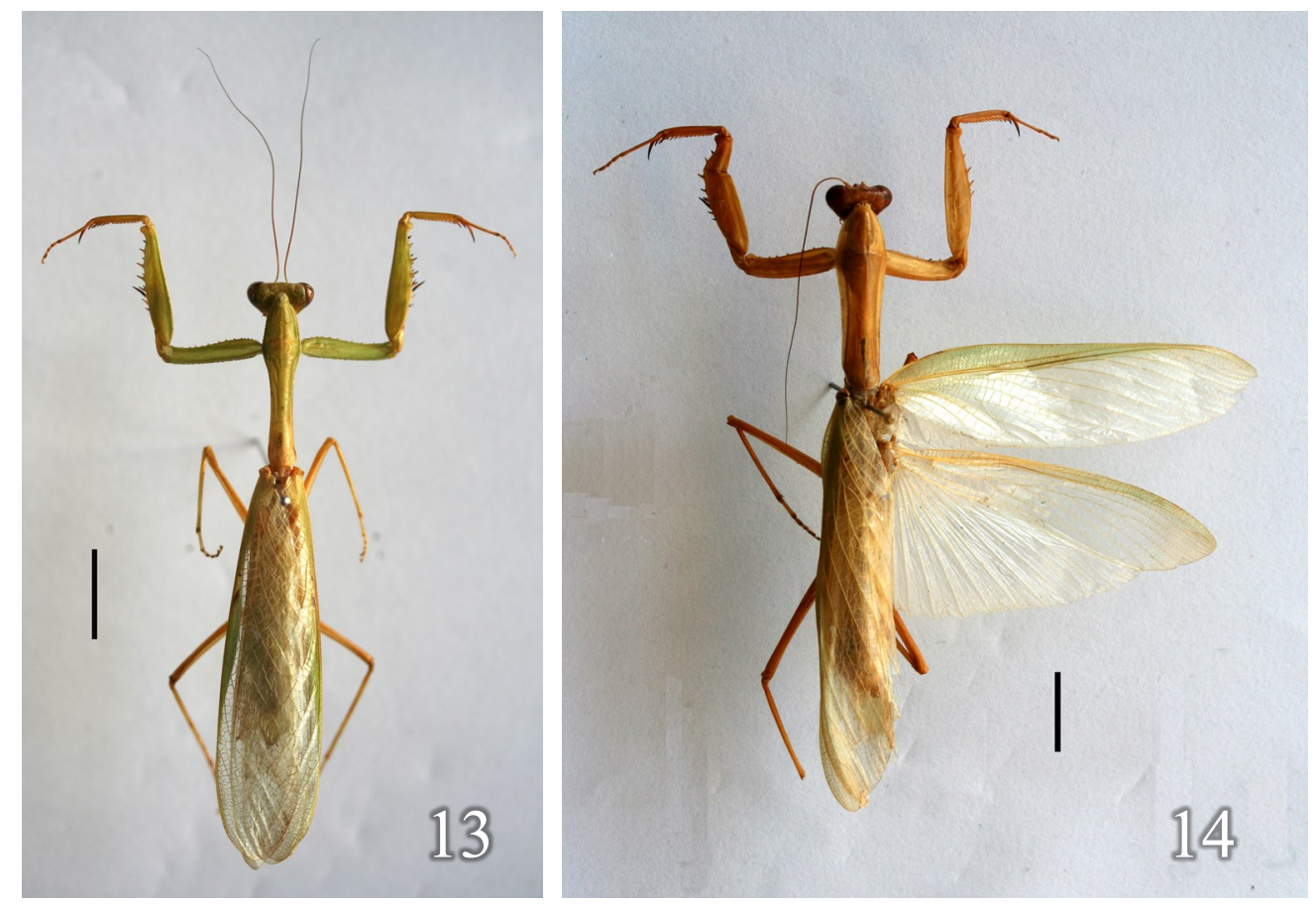

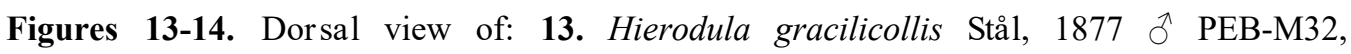
14. Hierodula sp. $\mathrm{H} 3$ $઼$ PEB-M74. Scale: $1 \mathrm{~cm}$. 

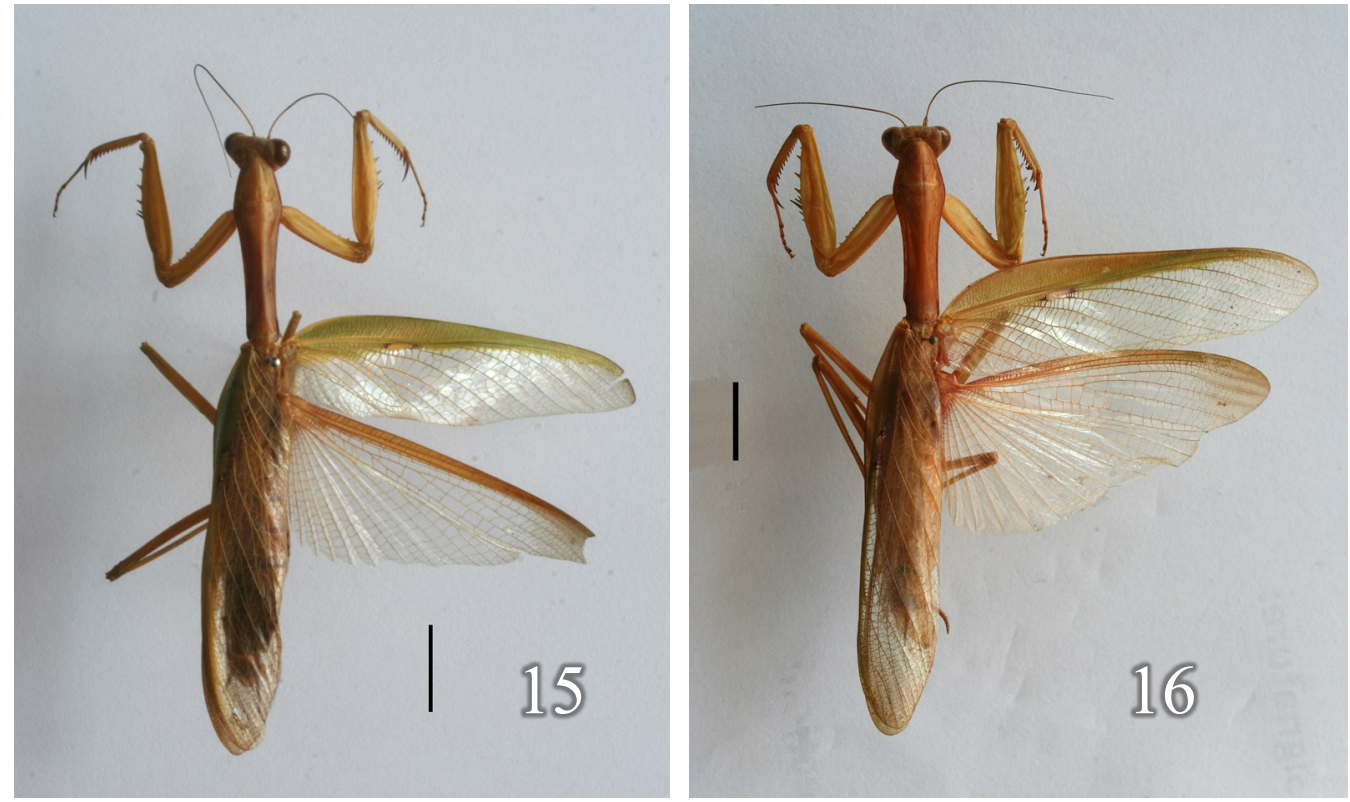

Figures 15-16. Dorsal view of: 15. Hierodula sp. H4 $\widehat{\partial}$ PEB-M40, 16. Hierodula sp. H5 $\delta^{\lambda}$ PEB-M45. Scale: $1 \mathrm{~cm}$.

\section{ACKNOWLEDGMENTS}

I thank Jack Rieley of Nottingham University for the opportunity to accompany the "For Peat's Sake" botanical team in Kelembenkari, and Paul Jenkins for sending me material collected after my visit. I thank Martin Stiewe (Natural History Museum, London, U.K.) and Emmanuel Delfosse (Museum National d'Histoire, Paris, France) for assistance with obtaining some literature. Christian Schwarz (Ruhr University, Germany) kindly provided some literature and helpful comments on the manuscript.

\section{REFERENCES}

Beier, M. 1934. Mantodea, Fam. Mantidae, subfam. Hymenopodinae. Genera Insectorum, 196: 1-37 $\& 2$ plates.

Beier, M. 1935. Mantodea, Fam. Mantidae, subfamilie: Mantinae. Genera Insectorum, 203: 1-146 \& 8 plates.

Beier, M. 1937. Results of the Oxford University expedition to Sarawak (Borneo), 1932. Mantodea. Proceedings of the Royal Entomological Society, 6(9): 177-181.

Beier, M. 1956. Mantiden aus Ceylon (Orth.) Ergebnisse einer Sammelreise von F. Keiser nach Ceylon 1953/54. Verhandlungen der Naturforschenden Gesellschaft Basel, 67(1): 33-40.

Beier, M. 1958. Mantiden aus dem Museum Zoologicum Bogoriense (Orthoptera). Treubia, 24(2): 245-247.

Bragg, P.E. 1995. Comments on the species of Phasmida described by Stoll in 1788 and named by Olivier in 1792. Phasmid Studies, 4(1): 24-25.

Bragg, P.E. 1996. Type specimens of Phasmida in the Nationaal Natuurhistorisch Museum, Leiden (Insecta: Phasmida). Zoologische Mededelingen Leiden, 70(6): 105-115. 
Bragg, P.E. 1997a. Rearing semi-aquatic cockroaches. Blattodea Culture Group, 11(1): 7-9.

Bragg, P.E. 1997b. An Introduction to Rearing Praying Mantids. P.E. U.K.: Bragg, Ilkeston.

Bragg, P.E. 2001. Phasmids of Borneo. Natural History Publications (Borneo).

Bragg, P.E. 2005. A new species of the genus Baculofractum, the first record of the genus from Borneo. Phasmid Studies, 13(1\&2): 31-37.

Bragg, P.E. 2008a. Notes on Necroscia haanii Kirby, 1904 from Borneo, including a new synonym. Phasmid Studies, 17(1): 27-33.

Bragg, P.E. 2008b. Praying mantids from the 'Gladiator' Expedition to the Brandberg Massif, Namibia, in 2002 (Insecta: Mantodea). Entomologist 's Monthly Magazine, 144: 173-179.

Bragg, P.E. 2010. A review of the Liturguisidae of Borneo (Insecta: Mantodea). Sepilok Bulletin, 12: 21-36.

Brunner von Wattenwyl, K. 1898. Orthopteren des Malayischen Archipels (Mantodea). Gesammelt von Prof. Dr. W. Kükenthal in den Jahren 1893 u. 1894. A bhandlungen herausgegeben von der Senckenbergischen naturforschenden Gesellschaft, 24(2): 193-288, pl. 16-17.

Delfosse, E. 2009. Taxonomie, biogéographie et biologie de deux espèces de mantes asiatiques du genre Deroplatys Westwood, 1839, et notes sur trois autres placées dans le même genre (Insecta: Mantodea: Mantidae). Le bulletin d'Arthropoda, 39(1): 4-28.

Ehrmann, R. 2002. Mantodea Gottesanbeterinnen de Welt. Munster: Natur und Tier Verlag. ISBN 3931587-60-6.

Giebel, C.G.A. 1861. Neue ostindische Schrecken. Zeitschrift für die Gesammten Naturwissenschaften, 18: 111-121.

Giglio-Tos, E. 1915. Mantidi Esotici VIII. Acromantinae. Bollettino dei Musei di Zoologia ed Anatatomia Comparata della R. Università di Torino, 30(702): 1-16.

Giglio-Tos, E. 1927. Orthoptera, Mantidae. Das Tierreich, 50: 1-707. Berlin: Walter de Gruyter \& Co.

Haan, W. de 1842. Bijdragen tot de Kennis Orthoptera. In: C.J. Temminck, ed. Verhandelingen over de natuurlijke Geschiedenis der Nederlandsche overzeesche Bezittingen. Volume 2.

Hebard, M. 1920. Studies in Malayan, Papuan and Australian Mantidae. Proceedings of the Academy of Natural Sciences of Philadelphia, 72: 14-82, plates 1-2.

Helmkampf, M.E., Schwarz, C.J. \& Beck, J. 2007. A first look at the biodiversity of praying mantids (Insecta: Mantodea) in Sabah, Borneo. Sepilok Bulletin, 7: 1-13.

Kirby, W.F. 1904. A Synonymic Catalogue of Orthoptera, Volume 1. London: British Museum (Natural History).

Lichtenstein, A.A.H. 1796. Catalogus Musei zoologici ditissimi Hamburgi, d III Februar 1796. Auctionis lege distrahendi. Section 3. Hamburg.

Lichtenstein, A.A.H. 1802. A dissertation on two Natural Genera hitherto confounded under the name of Mantis. Transactions of the Linnean Society of London, 6: 1-39, plates 1-2.

Ling, K.L., Hamid, A.A., Chey, V.K., \& Nazrah, M. 2013. Preying mantis of Sabah with special reference to Lower Kinabatangan and Danum Valley. Sepilok Bulletin, 17-18: 77-88.

Nazirah, M., Ling, K.L., Nurain, M. \& Chey, V.K. 2015. Diversity of Preying Mantis (Mantodea) in different habitat types in Sabah, Malaysia. Sepilok Bulletin, 21-22: 17-26.

Olivier, A.G. 1792. Encyclopédie Méthodique, ou par Ordre de Matières; par un Société de Gens de Lettres, de Savans et d'Artistes. - Histoire Naturelle. Volume 7. Paris.

Prete, F.R., Wells, H., Wells, P.H. \& Hurd, L.E. [editors] 2000. The Praying Mantids. Baltimore: The Johns Hopkins University Press.

Roy, R. 1967. Contribution à la connaissance des Amorphoscelis de la région orientale (Mantodea Amorphoscelidae). II. Les espèces d'Extrême-Orient. Bulletin de la Société entomologique de France, 71, 261-273. 
Roy, R. 2001. Contribution à la connaissance des Angelinae de la région orientale: les genres Euchomenella, Mythomantis et Tagalomantis (Dictyoptera, Mantidae). Revue française d'Entomologie (N.S.), 23(1): 79-92.

Roy, R. 2011. Les Amorphoscelinae Indo-Malais (Mantodea, Amorphoscelidae). Revue française d'Entomologie (N.S.), 32(1-2): 65-92.

Roy, R. 2013. Révision du genre Pachymantis Saussure, 1871 (Mantodea, Hymenopodidae). Bulletin de la Société entomologique de France, 118(2): 145-154.

Saussure, H. de 1870. Additions au Système Mantides. Mittheilungen der Schweizerischen Entomologischen Gesellschaft, 3(5): 221-244.

Saussure, H. de 1871. Mélanges Orthoptérologiques. IV Mantides. Mémoires de la Société de Physique et d'Histoire Naturelle de Genève, 21(1): 1-214 \& plates 4-6.

Schwarz, C.J. \& Konopik, O. 2014. An annotated checklist of the praying mantises (Mantodea) of Borneo, including the results of the 2008 scientific expedition to Lanjak Entimau Wildlife Sanctuary, Sarawak. Zootaxa, 3797(1): 130-168.

Schwarz C.J. \& Roy, R. 2018. Some taxonomic and nomenclatural changes in Mantodea (Dictyoptera). Bulletin de la Société entomologique de France, 123(4): 451-460.

Schwarz, C.J. \& Roy, R. 2019. The systematics of Mantodea revisited: an updated classification incorporating multiple data sources (Insecta: Dictyoptera). Annales de la Société entomologique de France (N.S.), 55(2): 101-196.

Schwarz, C.J. \& Shcherbakov, E. 2017. Revision of Hestiasulini Giglio-Tos, 1915 stat. rev. (Insecta: Mantodea: Hymenopodidae) of Borneo, with description of new taxa and comments on the taxonomy of the tribe. Zootaxa, 4291(2): 243-274.

Shcherbakov, E., Ehrmann, R. \& Borer, M. 2016. Revision of the genus Heliomantis Giglio-Tos 1915 (Insecta: Mantodea: Hymenopodidae). Annales de la Société entomologique de France (N.S.), 52(3): 135-149.

Sjöstedt, Y. 1930. Orthopterentypen im Naturhistorischen Reichsmuseum zu Stockholm. Arkiv för Zoologi, 21A(32): 1-43, 18 plates.

Stål, C. 1877. Systema Mantodeorum, Essai d'une Systématisation Nouvelles des Mantodées. Bihang Till K. Svenska Vet. Akad. Handlingar, 4(10): 3-91 \& 1 plate.

Stoll, C. 1787-1813. Représentation des Spectres ou Phasmes, des Mantes, des Sauterelles, des Grillons, des Criquets et des Blattes des quatre Parties du Monde. L'Europe, L'Asia, L'Afrique et L'Amerique; ressemblées et déscrites. Amsterdam. [Published in two parts, pages 1-56 and plates 1-18 in 1787 or 1788(?), and the remainder in 1813]

Supreme Court of Indonesia 2008. Document accessed January 2021, at 840-k-pdt-sus-2008.pdf (wordpress.com)

Werner, F. 1922. Philippine mantids or praying insects. Philippine Journal of Science, 21(2): 147$159 \& 1$ plate.

Werner, F. 1930. Über asiatische Mantidae aus dem naturhistorischen Reichsmuseum in Stockholm. Arkiv för Zoologi, 21A(34): 1-10 pl. 1-3.

Werner, F. 1933. Fünfter Beitrag zur Kenntnis der Mantodeen von Neiderländisch-Indien. Treubia, 14: $255-272$, \& plate 8 .

Wieland, F. 2008. The genus Metallyticus reviewed (Insecta: Mantodea). Species, Phylogeny and Evolution, 1(3): 147-170.

Woodward, B.B. 1915. Catalogue of the Books, Manuscripts, Maps and Drawings in the British Museum (Natural History), volume 5 SO-Z. London: British Museum. 